\title{
Contextual Learning on Mathematical Subjects to Enhance Student Motivation for Learning in Vocational High School
}

\author{
Andes Safarandes Asmara ${ }^{1}$, Hardi ${ }^{2}$, Yusi Ardiyanti ${ }^{3}$ \\ ${ }_{1}^{1}$ Universitas Buana Perjuangan, Jawa Barat-Indonesia \\ ${ }^{2}$ Institut Agama Islam Negeri Surakarta, Indonesia \\ 3Universitas Singaperbangsa Karawang, Jawa Barat-Indonesia \\ Email: andes@ubpkarawang.ac.id, hardi_sin@yahoo.com, yusi.ardiyanti@staff.unsika.ac.id
}

\begin{abstract}
The problem of learning in mathematics is because students always look at mathematics is complicated and usually exacerbated by the use of minimal learning aids. It needs to be given a fun learning solution for students to have the motivation and willingness to learn mathematics. One of them is contextual learning. This research wants to see the extent to which contextual learning can improve student learning motivation. This study uses qualitative research with the type of action research class (PTK) using the implementation cycle to see increased motivation and student learning outcomes. The results showed an increase in the motivation percentage of learning to study as a whole for each indicator of the first cycle of $62,89 \%$ to $73.42 \%$ motivation to study in cycle II for learning outcomes experienced Increase in high category with gain Sebsar 0.71. Based on the data, it has been noted that with contextual learning, it can improve student motivation and learning outcomes.
\end{abstract}

Keywords: Contextual Learning; Learning Motivation; Vocational Students

\section{Introduction}

Mathematics as a discipline that relies on the thought process, and is considered very good to be taught to the students (Syahbana, 2012). Learning math will give us a cognitivedevelopmental effect that leads to more complex thinking abilities. The more often students devote their efforts to learning mathematics will form thoughts that lead to a more elaborate point of view of a mathematical concept (John et al., 2016). Dalah, because there are still many students who do not like mathematics, in SMK Negeri 1 Cikampek, for example, the tendency of students in this school is less fond of math lessons and very difficult to learn mathematics. As large as students state that math lessons are difficult and tried to find answers to questions given, one of them is geometry material.

Geometry is a branch of mathematics that relates to form and space. Students in learning geometry are difficult or experiencing obstacles when understanding the form. Many students fail to develop a good understanding of the concept of geometry, geometry reasoning, and the skills of a Geometry problem solving (Saha, 2010). Other studies have also mentioned that difficulties are learning geometry in configuring Understanding (Lin and Lin, 2013). Based on the fact in the field, students at SMK SMK Negeri 1 Cikampek are not satisfactory or are sufficiently far below the standard value of graduation subjects that have the value of minimal submission criteria (KKM) 75.

Poor value conditions are also supported by learning tools such as mathematics learning media or props that have not been used optimally. Students only get information or knowledge about mathematics from explanations given by teachers while in class. The absence of a handbook or reference book used by students to learn extends the list of causes of student learning difficulties. Based on the results of an interview with one of the teachers of mathematics at SMK Negeri teachers still dominate 1 Cikampek West JavaIndonesia, teaching and learning activities conducted in the school. Students ' involvement in learning is still very lacking. The teaching method used by the teacher, in general, is the lecture method, in which teachers explain the material to the students, while the students listen and record the teacher's explanation. The result of such learning is that students are less actively involved in learning. This method is less desirable for students. Consequently, students ' interest in following the lesson is reduced. It is demonstrated by the lack of 
enthusiastic students in the following learning and teaching activities (KBM), including in math subjects. Thus, it is necessary to provide a pleasant learning solution for students in SMK Negeri 1 Cikampek so that they have the motivation and willingness to learn mathematics. If this motivation and willingness of learning arise, then the increase in the value of learning will follow.

Contextual learning can be alternative learning suitable for students of SMK Negeri 1 Cikampek West Java-Indonesia. It is intended for learning to be made closer to what they have applied daily in their lives. Contextual learning is a learning process aimed at helping students connect the subject matter with a context in the lives of students (Bustami, DKK. 2018). A contextual Model is a learning concept that considers a child learning to be better if the environment is scientifically created, meaning learning will be more meaningful if students experience what they learn, not just know. Learning is not merely the activity of transferring knowledge from teachers to students, but how students are able to interpret what is learned (Kadir, 2013).

Johnson (Maryati, 2017) mentions that contextual learning is an educational process aimed at helping students see the meaning in the learning materials they are learning by linking them to everyday contexts. With the context of personal, social and cultural environments and eight key CTL principles are: having meaningful relationships, working on meaningful work, organizing our learning way, working together, thinking critically and creatively, nurturing/caring for Students ' personal, achieving high standards, and using authentic assessment. In learning with the contextual approach Contextual Teaching and Learning (CTL), The teacher serves as a facilitator that helps students to associate the knowledge gained with the real-world situation of the students.

There are 14 student-centered learning principles (student centers or learners centered) acquired by The American Psychological Association (APA) Board of Educations Affairs as described in Januszewski (2009:39): Apa'S Learner-Centered Psychological principles: (1) Nature of learning process, (2) Goal of the learning process, (3) Construction of Knowledge, (4) Strategic thinking, (5) Thinking about thinking, (6) Contex of Learning, (7) Motivational and emotional influences on learning, (8) Intrinsic motivation to learn, (9) Effect of motivation on effort, (10) Developmental Influences on Learning, (11) Social Influences on Learning, (12) Individual Differences in learning, (13) Learning and Diversity, (14) Standard and assessment.

The expected consequence is that students make the relationship between his knowledge with his application in their daily lives as family members and communities. Thus, students can know the benefits that he or she will be able to learn from the subjects. If students already know the benefits of the thing he learns, then he will be motivated to learn.

Arianti (2018) reveals that motivation is a psychological condition that encourages someone to do something. There are several main components of motivation, namely: 1). The need, when the individual feels there is an imbalance between what he or she has hoped for; 2). The impulse is the mental strength to perform activities in order to fulfill expectations, and 3). Impulse is a mental power oriented to the fulfillment of expectations or achievement of objectives. The goal is to be accomplished, and the goal will lead to conducting in this case, which is the behavior to learn.

Description of the importance of motivation to teach the reason researchers to research the implementation of contextual learning on mathematics subjects in SMK Negeri 1 Cikampek West Java-Indonesia, especially mathematics learning Class XI.

\section{Research Methods}

The research conducted using a qualitative approach with this type of research is collaborative and participatory Classroom Action Research (PTK). Collaborative means in this research, researchers cooperate with mathematics teachers in class XI SMK Negeri 1 Cikampek Karawang. While participatory means the researchers who assisted the mathematics teachers are directly involved in the research. PTK is used because it has several traits; the number is 1). Based on the problems faced by teachers in the process of teaching and learning; 2). collaboration in implementation; 
3). Researchers, as practitioners do reflections; 4). aims to improve the quality of learning practices, and 5). Carried out in several cycles (Triyono, 2008).

This class action research was conducted at SMK Negeri 1 Cikampek District

Karawang. At the stage of determining the subject, the researcher consulted with a Gonilan curriculum to ask the students in the XI class as the subject of the study, then based on the subject of his research of Xi grade chemical analyst student, which amounted to 35 people. The study carried out two cycles with four meetings on each cycle, so a total of 8 meetings. Each implementation of the cycle to see the achievement of increased motivation and learning outcomes. Each performed cycle meets the criteria as described below:

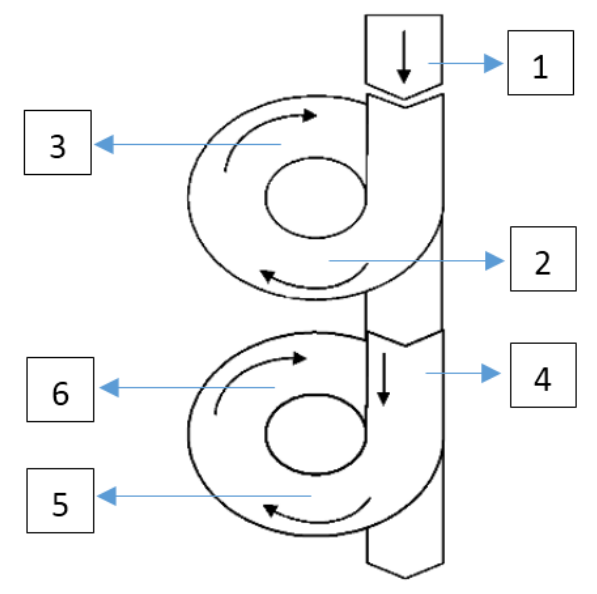

Figure 1. Cycle Research Action Model class Kemmis \& Taggart (2014)

Description

1. Planning

2. Actions and Observations I

3. Reflection

4. Plan files I/action planning II

5. Action and Observation II

6. Reflections

The motivational data collection techniques used in this study include observation, interviews, polls, and documents, while the outcomes of study through formative tests in the form of essays were carried out two times, namely the end of Cycle 1 and cycle 2.

\section{Results and Discussion}

This class of action research has several threads. The planning phase of the researcher to perform step 1) reviewing the subject matter, preparing the syllabus, and the Learning Plan, and the student activity sheet, 2) preparing and Reviewing evaluation formats that consist of the final test of learning and motivational indicators, reviewing indicators to determine the success of the activities carried out, such as learning motivation assessment rubrics.

The implementation of the class action is the realization of an action that has been planned. The study carried out learning through two cycles. In cycle I, the subject matter studied in space geometry performed four times the meeting. One time meeting consists of $(4 \times 45$ minutes). While in cycle II for the subject matter geometry of the field held four times the meeting also. As for the execution steps of the action, in cycle I and cycle II as follows: Before the learning begins, the first step implemented by the teacher is to provide a productive question that is answered by students to know Students ' initial knowledge of the study materials to be discussed. Learning is done with steps to follow contextual learning, including a) constructivism; b) Ask; c) Find; d) Learning society; e) modeling; f) Reflection; g) Actual assessment. 
Reflections are conducted on the achievement of the students ' motivation and learning outcomes and seek out factors that cause students who do not have or lack motivation to study outcomes, seek action and seek solutions to the problem, and Effort to be made to improve it. Analysis conducted on the application of cycle I was evaluated and interpretation of the cause to be used as a reference in conducting improvement or repair during the learning process in cycle II.

Data on research results to see the motivation to learn in the learning process. Researchers observe the learning strategies applied by teachers who teach and interview the learning process that takes place using a poll to students. The indicators used in this research are three motivational indicators learning from six indicators, according to Uno (2011). The reason researchers use only three indicators is that the instrument is based on validation results after validation can be instrumented with three indicators. However, also in adjusting to the indicators and learning objectives used in the During the learning process, the motivation indicators used in instruments are 1) the presence of desire and desire, 2) there is encouragement and need in learning, 3) There are hopes or ideals of the future. The instruments used in this study are tests to measure learning outcomes. The test used is the final test of learning, which is arranged in the form of essay problems (10 questions for the cycle I and ten questions for cycle II).

Each cycle's final Test Data on motivation and student learning outcomes for space geometry material and field geometry is analyzed by converting the average value of each item to a problem on each indicator and entering the value conversion guidelines (value Gain) and indicators. It is to determine the level of motivation and student learning outcomes.

Based on the results of the evaluation at the end of the cycle I and II cycle have increased motivation and student learning outcomes. Increased motivation to learn from cycle I and II cycle can be seen in table 1 increased criteria based on Gain, for each motivation learning indicator, as follows:

Table 1: Learning Motivation Indicators

\begin{tabular}{clcccc}
\hline Number & Assessment Indicators & $\begin{array}{c}\text { The } \\
\text { Average } \\
\text { Value Of } \\
\text { The Cycle I }\end{array}$ & $\begin{array}{c}\text { The } \\
\text { Average } \\
\text { Value Of } \\
\text { The Cycle II }\end{array}$ & Gain & Category \\
\hline 1 & A successful desire and desire & 48,95 & 51,04 & 0,06 & Low \\
2 & $\begin{array}{l}\text { The encouragement and need } \\
\text { to learn }\end{array}$ & 50,69 & 76,38 & 0,9 & High \\
3 & Future expectations or ideals & 52,63 & 73,68 & 0,4 & Middle \\
\hline
\end{tabular}

The implementation of the Constectual learning used in this study received a positive response from the students, they felt enthusiastic during the learning process even though some students in the group were still in a blase with existing class conditions, could Judge from the learning motivation of students who experienced an increase from cycle I to cycle II. The improvement of each indicator for motivation learning is diverse. The desire to succeed in obtaining the lowest increase by the average value of the cycle I is 48.95 to 51.04 . Motivational indicators with an increase in presence in the indicator of future expectations or ideals of 52.63 in cycle I to 73.68 in cycle II. While the indicators that get the highest increase are the boost and need in learning by 50.69 in cycle I to 76.38 in cycle II.

It is due to several possible factors, i.e., 1) students have had the experience of following the learning with the implementation of contextual learning in cycle I so that students are able to adapt to the learning atmosphere, 2) the existence of Information about technical explanations and the students ' weaknesses in following teacher learning, causing students to apply specific strategies as a form of anticipation, 3) There are guidelines for facilitating the completion process, and 4) The delivery of student learning outcomes both individually and in groups, create a positive feeling towards the students, to compete in 
obtaining better learning outcomes. It can also be seen in graph 1. about the average increase in motivation results of learning from cycle I to cycle II. It is seen below experienced an increase from the amount of 2390 or $62,89 \%$ to 2790 , or $73.42 \%$ overall.

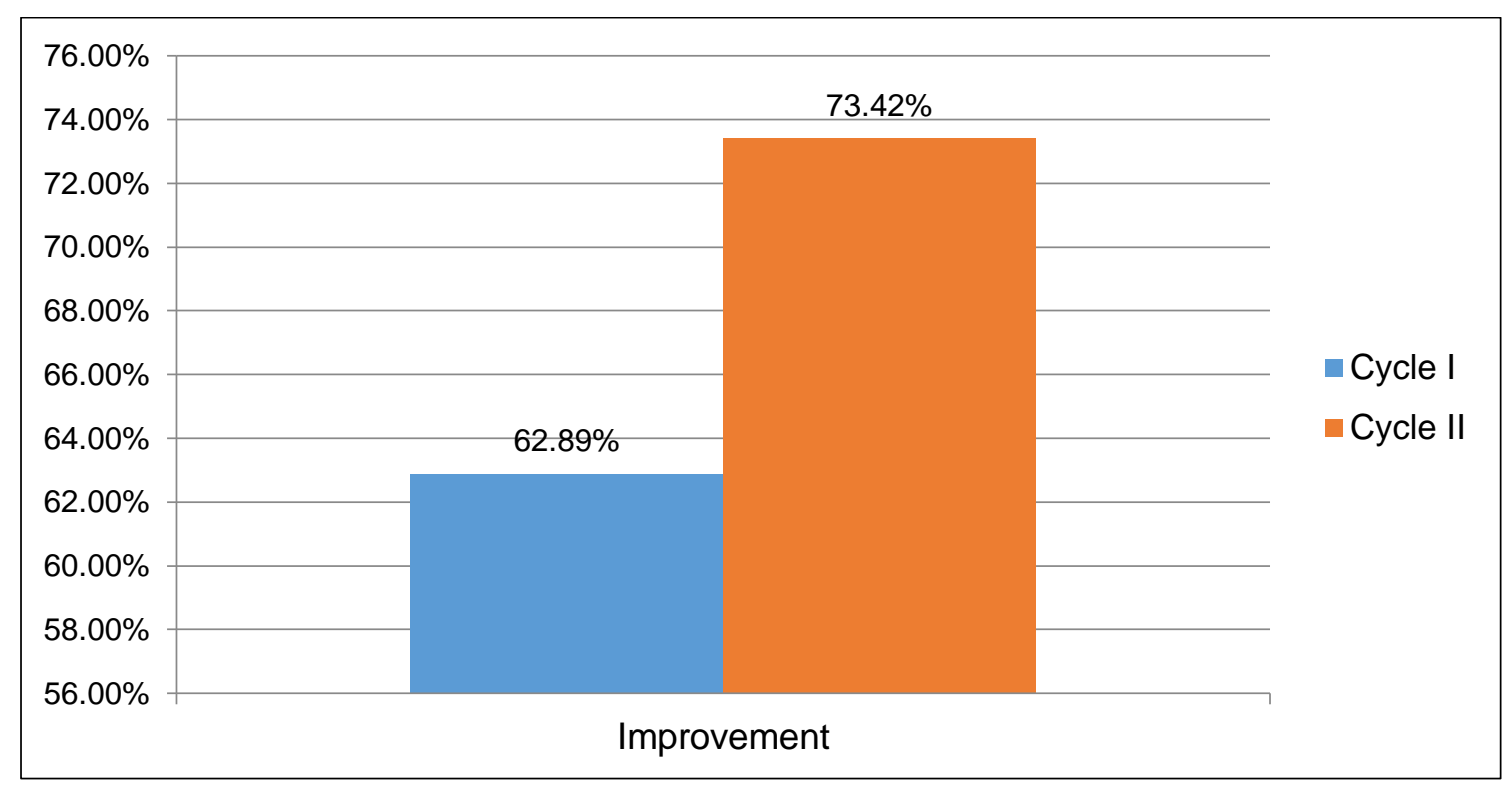

Figure 2: Improved Motivation Learning Results From Cycle I and Cycle II

The graph shows an increase in overall motivation for learning. However, the results of each indicator are the author of the analysis. The author uses only three indicators from six indicators available, and all indicators are improved, one indicator reaches a low category (indicators of encouragement and need in learning). One High-category indicator (the indicator of future expectations or ideals) is also another indicator of the Moderate category improvement (indicators of desire and desire). It is visible from the chart below:

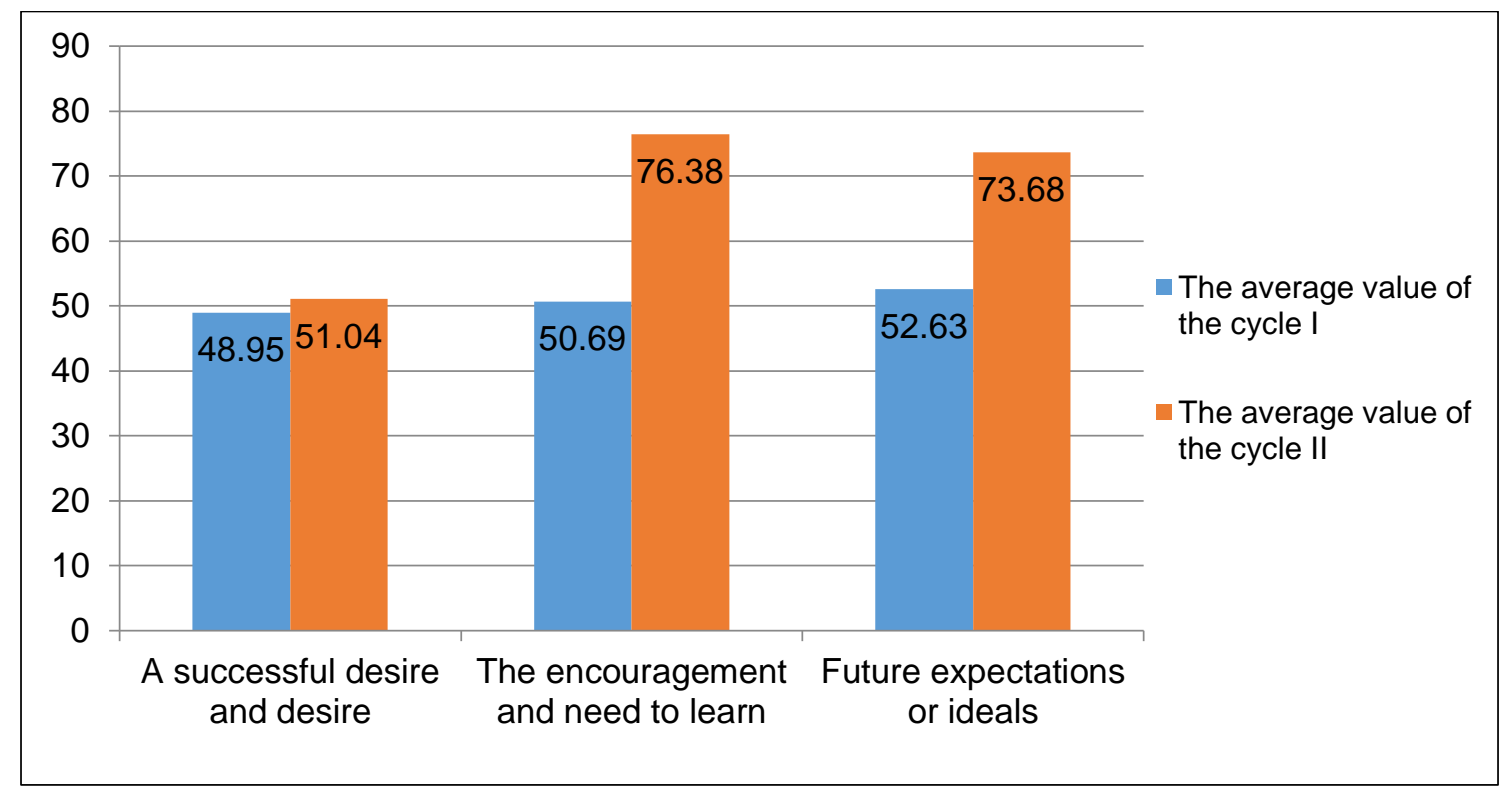

Figure 3: Increased Motivation for Learning Each Indicator of Each Cycle

Low student initial motivation is one of the factors that determine the success rate of the student learning process. Thus fundamental knowledge is information as a reflective 
material for teachers to plan a learning strategy. It is because one indicator of the quality of the learning process is to associate the initial knowledge that the students have with the study material that will be discussed (Depdiknas, 2003).

As a result of early students, knowledge is low. It is necessary to plan for learning that gives students a real experience. One of them is to implement contextual learning. The context presented in a context that is often found in real-life every day. Through the application of this learning, students can follow the procedures of constructivism learning, asking, discovering, learning society, modeling, and reflection; Data of observation results. It is in line with Edgar Dale mentioned that his highest learning experience is a real learning experience. While the lowest is the abstract learning experience (Ali, 2010).

The implementation of contextual learning in mathematics learning was generally positively responded to by students. It is evident from the seriousness and attendance of students following learning. Contextual deployments can increase the student's motivation and interest to learn better. It is following the opinions of Ayan (2002), stating that in the process of learning, the new ways and styles presented to students, generally arousing students ' curiosity and increasing motivation to learn. Curiosity encourages someone to investigate a new field or find out how to do things better.

The application of contextual learning can also optimize learning experiences, such as experience observing, learning in groups, and communicating knowledge. This situation encourages action and reflection on the students, to respond promptly to new learning situations. The learning that involves the complete sense will be more meaningful than a single sensory. It can be proved by the learning outcomes for geometry material, as shown in table 2.

Table 2: Average learning outcomes for cycles I and II

\begin{tabular}{ccccc}
\hline Learning outcomes & Cycle I & Cycle II & Gain & Category \\
\hline Geometry & 60,60 & 70,80 & 0,71 & High \\
\hline
\end{tabular}

Based on the above result can be known that the results of the study conducted by the students in geometry material also increased from an average of 60.60 to 70.80 , which means experiencing a high category increase by 0.71 . Such improvement can be due to several factors, including the possibility of using learning that uses other strategies than usual, causing interest and motivation to learn. When the interest and motivation of learning are high, then students will be comfortable to focus on being able to understand the materials that are being discussed. It is in line with the expressed by Kompri (2015), which mentions that one feature that students are quickly focused and highly motivated if the environmental condition, in this case, the learning process is conducive so that the learning outcomes will be Optimal (Maja, 2013).

\section{Conclusion}

Based on the results of research and discussion, it can be concluded that: broadly, the learning components with a contextual approach have been carried out well; The motivation and outcome of learning from the students of XI SMK Negeri 1 Cikampek West Java-Indonesia increased by preparing mathematics learning with the contextual approach. In this study, the study had only increased motivation based on three indicators from 6 indicators. For further study, the overall motivation indicator can be sought to see the results of learning on the same or different material.

\section{Reference}

Ali, M. (2010). Guru Dalam Proses Belajar Mengajar (14th ed.). Sinar Baru Algensindo.

Arianti. (2018). Peranan Guru Dalam Meningkatkan Motivasi Belajar Siswa. Didaktika Jurnal Kependidikan, 12(2), 117-134. https://doi.org/10.30863/didaktika.v12i2.181 
Ayan, J. E. (2002). No TitleBengkel kreativitas: 10 cara menemukan ide-ide pamungkas melalui pergaulan, lingkungan, perjalanan, permainan, alam bawah sadar, seni, teknologi, berpikir, bacaan, jiwa kreatif (1st ed.). Bandung: Kaifa. Retrieved from http://uilis.unsyiah.ac.id/uilis/index.php?p=show_detail\&id=8289

Bustami, Y., Syafruddin, D., \& Afriani, R. (2018). The implementation of contextual learning to enhance biology students' critical thinking skills. Jurnal Pendidikan IPA Indonesia, 7(4), 451-457. https://doi.org/10.15294/jpii.v7i4.11721.

Depdiknas. (2003). Kurikulumberbasis Kompetensi. Jakarta: Pusat Kurikulum, Balitbang Depdiknas.

Januszewski, A. and M. M. (2009). Educational Technology: A Definition with Commentary. British Journal of Educational Technology, 40(1), 185-195. https://doi.org/10.1111/j.1467-8535.2008.00925_4.x

Kadir, A. (2013). Konsep pembelajaran kontekstual di sekolah. Dinamika IImu, 13(3), 17-38. https://doi.org/10.21093/di.v13i1.20

Kompri. (2015). Motivasi Pembelajaran Perspektif Guru dan Siswa (1st ed.). Bandung: PT Remaja Rosdakarya. Retrieved from https://rosda.co.id/pendidikan-keguruan/494motivasi-pembelajaran-perspektif-guru-dan-siswa.html

Lin, J. J. H., \& Lin, S. S. J. (2014). Cognitive Load For Configuration Comprehension In Computer-Supported Geometry Problem Solving: An Eye Movement Perspective. International Journal of Science and Mathematics Education, 12(3), 605-627. https://doi.org/10.1007/s10763-013-9479-8

Maja, I. (2013). Pengaruh Motivasi, Metode Pembelajaran Dan Disiplin Belajar Terhadap Prestasi Belajar Matematika Teknik Di Politeknik Negeri Sriwijaya. Jurnal Orasi Bisnis, IX(Mei), 34-47.

Maryati, I. (2017). Peningkatan Kemampuan Penalaran Statistis Siswa Sekolah Menengah Pertama Melalui Pembelajaran Kontekstual. Jurnal Mosharafa, 6(1), 129-140. https://doi.org/10.31980/mosharafa.v6i1

Saha, R. A., Ayub, A. F. M., \& Tarmizi, R. A. (2010). The effects of GeoGebra on mathematics achievement: Enlightening Coordinate Geometry learning. In Procedia Social and Behavioral Sciences (Vol. 8, pp. 686-693). https://doi.org/10.1016/j.sbspro.2010.12.095

Stephen Kemmis, Robin McTaggart, R. N. (2014). The Action Research Planner Doing Critical Participatory Action Research. Springer Singapore Heidelberg New York Dordrecht London: Springer Science+Business Media Singapore. https://doi.org/10.1007/978-981-4560-67-2

Syahbana, A. (2012). Peningkatan Kemampuan Berfikir Kritis Matematis Siswa SMP melalui Pendekatan Con. Edumatica: Jurnal Pendidikan Matematika, 02(1), 45-57. Retrieved from https://online-journal.unja.ac.id/index.php/edumatica/article/view/604

Triyono. (2018). Penelitian Tindakan Kelas: Apa Dan Bagaimana Melaksanakannya? Seminar Guru-Guru se UPDT Sumpiuh, Banyumas. https://doi.org/10.13140/RG.2.2.26385.12649

Uno, H. B. (2011). Teori Motivasi dan Pengukurannya (15th ed.). Jakarta: Bumi Aksara.

Yohanes, B., Matematika, P., \& Malang, P. N. (2016). Beban Kognitif Siswa Dalam Pembelajaran Materi Geometri. Jurnal Pendidikan - Teori, Penelitian, Dan Pengembangan, 1(2), 187-195. https://doi.org/10.17977/jp.v1i2.6121 